\title{
The religious switching of immigrants in Canada
}

Although the contribution of immigration and religious switching to the changing religious landscape in Canada seems well established, we lack knowledge on the religious switching of immigrants. In this study we address if and to what extent immigrants to Canada change religion after their arrival. We use data on religious affiliation and other demographic characteristics from the 1981, 1991 and 2001 censuses, as well as from the 2011 National Household Survey and the 2002 Ethnic Diversity Survey to study, in a demographic perspective, the magnitude of religious switching among the immigrant population to Canada across the 30 years of observation. We compare it with the religious switching of the Canadian-born population and look for characteristics associated with religious switching among the population of immigrants. The results show that the patterns of religious switching of immigrants presents similarities with that of the Canadian-born even if, in relative terms, net population change associated with religious switching are of a lower magnitude among the immigrant population in the most recent period. Religious background and place of birth appear to be related to religious change among immigrants in Canada.

Keywords: Canada; religion; religious switching; immigration; secularization

\section{Introduction}

Many countries are going through profound transformations with regard to religions that have been referred to as a "soft revolution” (Goujon et al. 2014; Goujon and Bauer 2015). 'Revolution’ because it affects Christianity which has long been considered a central element of the cultural foundation of these countries (Halman and Riis 2003) and 'soft' because it is neither violent nor sudden, nor is it an organised movement but rather a development that progresses gradually but surely through different societal and demographic mechanisms. This phenomenon is particularly acute in Europe where many Europeans have a low sense of religious belonging, having become secularised or turned towards other forms of spirituality. On the other hand, religious diversity is on the rise, as many European countries have become major receivers of international 
migration during the last decades. The increasing stock of international migrants, as well as second and further generations, is the main driver of socio-demographic, cultural, ethnic and religious diversity in destination countries, where new arrivals have come with an array of religious denominations that previously were often just marginal or non-existent. While the intensity might be different in the United States with overall lower shares of unaffiliated and of religious diversity brought by migrants, the trend goes in the same direction as in Europe.

Canada is also experiencing such changes. Between 1981 and 2011, the percentage of Christians in the population decreased from $90 \%$ to $67 \%$ and among them, the two predominant Christian religions, namely the Catholic and Protestant denominations, saw their share decline from $88 \%$ to $61 \%$. During the same period, the share of the population reporting no religion increased from $7 \%$ to $24 \%$ and that of the population belonging to non-Christian religions increased from 3\% to 9\% (Statistics Canada 2013; Pew Research Center 2013). These trends are projected to continue (Morency et al. 2017).

Like in Europe and in the United States, two main phenomena explain the changes observed in Canada's religious composition: religious switching and international migration. To the latter, since the end of the 1990s, net international migration surpassed natural increase as the main component of population growth (Statistics Canada 2008) and the projections (Statistics Canada 2014) show that it is not likely to reverse, at least not in the short or medium term. Of the 33 million Canadians enumerated in 2011, 7 million persons representing $21 \%$ of the population were immigrants or, in other words, persons who were granted by immigration authorities the right to live permanently in Canada (Statistics Canada 2013-2). Since immigrant 
populations in Canada increasingly come from non-European countries (Chui et al. 2007; Statistics Canada 2013), their religious composition differs more and more from that of the native population. Among immigrants, the Catholics and Protestants represent indeed a diminishing share (from $75 \%$ in 1981 to $43 \%$ in 2011), while nonChristian affiliations are growing: from 9\% in 1981 to 26\% in 2011. The data for 2011 show an overrepresentation of the non-Christian religions among the immigrant population when compared to the total Canadian population and an underrepresentation of the Catholic, Protestant and No religion groups (Figure 1).

[Insert Figure 1 about here]

The second trend which also largely explains the changing religious landscape of Canada over the last 30 years is that of religious switching, ${ }^{1}$ in particular disaffiliation (Goujon et al. 2015). Each subsequent census has revealed an increasing share of the population who do not adhere to any religious affiliation, in large part as a result of religious switching, either over the life course or from one generation to the next (Goujon et al. 2015; Pew Research Center 2013)². The disaffiliation trend took

1. For the purpose of this paper, religious switching refers to changes between all religious affiliations considered, including “no religion”. It thus includes switching between religious affiliations, religious apostasy (or disaffiliation) and switching from no religion to a religious affiliation. We acknowledge however that religious switching as defined here includes events which may have distinct dynamics.

2. The composition of immigrant cohorts at arrival also contributed until 2001 to increase the share of the population who report no religious affiliation but it is no longer the case. As opposed to the situation until the 2001 census, the 2011 National Household Survey shows 
place along with the decline in religious practice in the overall Canadian population (Colom Gonzalez and D'Amato 2016; Pew Research Center 2013), in a context of social changes where the institutional influence of the largest Christian denominations diminished and religion moves increasingly from the public to the private sphere of individuals (Swatos and Christiano 1999). However, the share who practice religion on a regular basis seems to have stabilized in recent years (Bibby 2012).

If the contribution of immigration and religious switching to the changing religious landscape in the countries of Europe and North America seems well established, we lack knowledge on that of the religious switching of immigrants after arrival. As we will show in the literature review, it is often expected and assumed that while adopting the way of life in the country of destination in terms of language and general manners, the migrants would retain their religion (Herberg 1960 cited in Ebaugh and Saltzman Chafetz 2000). As Eid (2007) notices, there is a general belief in Canada ${ }^{3}$ that immigrants from ethno-cultural minorities as opposed to non-immigrants from majority groups are strongly tied to their religion and are impervious to secularization. However, Eid mentions that these assumptions about fixed attributes of the different categories have not been tested. He finds similarities between immigrants and nonimmigrants in terms of disaffiliation but just analyses very briefly this question, and looks only at disaffiliation for persons having two parents of the same religion. Beyer (2005) has focussed on the contribution of selected cohorts of immigrants (with Asian,

lower shares of "no religion” among the most recent immigrants (landed since the last ten years) than within the non-immigrant population.

${ }^{3}$ Eid (2007) actually focuses on Quebec but his arguments seem valid for the rest of the country. 
Middle East and North African origins) to the religious landscape in Canada over time (until 2001) and argues against the main findings of Bibby (1993, 2000, 2002) that immigration to Canada does not necessarily lead to an increase in religious diversity. This author analysed the changing religious composition of immigrant cohorts after arrival to Canada, but was not able to isolate the religious switching factor per se. Connor $(2008,2009)$ looked at the religious trajectories of migrants in Canada but over a short time span. To our knowledge, no previous studies have empirically assessed the religious switching for the entire immigrant population in Canada for a long time period. And no study takes advantage of the most recent data to analyse the phenomenon.

In this study we examine, in a demographic perspective, the question of religious switching of immigrants to Canada after their arrival. The question has importance given that the foreign-born population, which represented more than $20 \%$ of the Canadian population in 2011, is projected to see its share increase and reach between 24 and 30\% by 2036 (Morency et al. 2017). As such, their contribution to the changes in the country's religious landscape through religious switching is likely to increase in coming years. This contribution may, of course, depend on key characteristics such as place of birth of the future immigrants or the evolution in the number of mixed unions. The on-going discussion on the place of religion in the public domain could benefit from a better understanding of the demographic dynamics currently at play. In a broader sense, it is important because the phenomenon of religious switching in the context of migration is one of the factors contributing to the integration of migrants and countries' social cohesion that receive considerable attention nowadays from politicians, the media, and the general public. Besides, this 
study contributes to Statistics Canada's most recent projections on the diversity of the Canadian population, which includes religious affiliations (Morency et al. 2017).

Using the 1981, 1991, 2001 censuses, the 2011 National Household Survey (NHS) and the 2002 Ethnic Diversity Survey (EDS), this paper analyses the religious switching among the immigrant population of Canada. More precisely, the following three research questions are considered: What is the magnitude of religious switching among the immigrant population to Canada and has it changed across the 30 years of observation? How does the religious switching of immigrants compare to that of the Canadian-born population? What are the socioeconomic characteristics associated with religious switching among the population of immigrants?

In the first part of the paper, we review the literature on immigration and religious switching. In the second part, we describe the concepts, data sources as well as methods used. The third part is dedicated to the analysis of results.

\section{Literature review}

Religious switching has been increasingly studied especially since it gained in importance in Northern America and Western Europe from the late 1960s (Breen and Hayes 1996). However, very little research has focused so far on the religious switching of the spatially mobile, the migrants, which is the main theme of this article. Much of the research that does exists in this area (see literature review in van Tubergen 2013) has focused on religious switching in terms of migrants' integration potential in the host society (Van Tubergen and Sindradóttir 2011; Foner and Alba 2008) and relates largely to the changes in religiosity intensity. 
This is also the case of the few recent studies that have focused particularly on the transmission of religious identity and level of religiosity from parents $\left(1^{\text {st }}\right.$ generation of migrants) to their children ( $2^{\text {nd }}$ generation migrants). The results can be context dependent, but find - in general - that religiosity diminishes with time spent in the host country in Western Europe (Inglehart and Norris 2009; Maliepaard, Lubbers \& Gijsberts 2010) whereas in the United States where religiosity levels are in general rather high migrants could be more likely to retain their level of religiosity (Ebaugh and Chafetz 2000). Another factor explaining the difference between the United States and Europe is that most migrants to the United States are Christians and therefore can "use" religion to integrate more rapidly whereas large segments of migrants to Europe come from Islam which is seen as hindering integration (Fleischmann and Phalet 2012).

In Canada, a few studies have also examined whether immigrants disaffiliate (secularize) or adopt a different religion, although most focused on the impact of immigration on the religious landscape, e.g. Beyer (2005) or Morency et al. (2017). Phillip Connor studied in depth the changes in religious affiliation among some of the immigrants to Canada a few years after arrival and found a rise in religious affiliation, however of temporary nature, with religiosity subsequently decreasing over time (Connor 2008, 2009). Bibby (2002) theorized based mostly on 1991 census data that Canada was prone to remain a Christian country in the near future, mostly since the majority of immigrants to Canada at this time were Christians. He also noticed that immigrants whether they are Roman Catholics, Protestants, Jewish, Buddhists, Muslims or Hindus would be inclined to maintain their religion of origin. In Canada, a study across generations has revealed that while immigrants to Canada having two parents with the same religion present low levels of disaffiliation, it does not apply to children 
born to Buddhist parents (Eid 2007). This study also showed similar disaffiliation levels between immigrants and non-immigrants having parents in the same religion. A study based on the analysis of Chinese immigrants (with a large majority being non-religious at the time of arrival) in Canada over three consecutive censuses found that the likelihood of having a religious affiliation increased over time - and that they were likely to become either Buddhist or Christian (Skirbekk et al. 2012).

As many immigrants arrive after the ages where religious change is most frequent, they may come "too late” to convert, which could decrease their overall levels of conversion. Younger adults are more likely to switch religious affiliation than older adults according to empirical studies from Europe and the United States (e.g. Crockett and Voas 2006; Wolf 2008). This decreasing propensity to religious switching over the course of life may be related to the increasing cost in human capital involved by such change, the cost being greater for individuals who invested more in religion, notably through regular religious practice (Iannaccone 1990).

It is clear that the levels of religious switching can differ not only by age, but also between religions and between countries where the immigrants were born. The religious switching estimates used by a set of global religion projections published under the PEW banner (Pew Research Center 2015; Stonawski et al. 2015) showed that Christians are losing members through net religious switching around the world though most of this switching occurs in North America and Europe. Leaving Islam is often illegal and conversion levels may therefore be low (Rahman 1986) although it is happening especially in Northern America. Further, even if generally experiencing net gains from religious switching, seculars have been found to be more likely to change 
religious view than members of religious groups, as evidenced in United States and Europe (Goujon et al. 2007; Skirbekk et al. 2010) as well as in Canada (Bibby 2004; Bibby 2007; Goujon et al. 2015).

There are also several reasons why we may see different levels of religious change in contemporary Canada than what has been observed in the past. Recent years has seen a broader societal acceptance of religious change and increased openness towards change in identity and belief (Bibby 2007). This could make changing or leaving one's religion relatively more acceptable in the Canadian setting, unlike the situation in nations where there has until now been a low general acceptance of religious conversion (Rambo et al. 2012). Also, there has been a growth in the prevalence of interreligious marriages in Canada (Clark 2006) and this could lead to more religious change and particularly religious decline, as children of interreligious couples tend to be less religious (Voas 2003).

Religious demand factors influence the processes underlying the decision of individuals to enter, leave or change religion (Engelberg et al. 2016, Iannaccone 2016). With greater economic opportunities, a more secular public debate and high levels of religious diversity than in their countries of origin which many migrants experience after immigrating to Canada, their desires for religion may change (Ellison and Levin 1998; Van Cappelen et al. 2016).

Migrants may perceive benefits from adopting a more similar culture as the native majorities, including adaptation to the majority religion - which could (or could be perceived to) lead to greater social acceptance in general, new group memberships 
and economic advantages. Migrants uprooted from their social and religious communities following migration may perceive the potential social and religious rewards of entering established communities in their destination country. Furthermore, the uncertainty, stress and challenges that occur during migration and belonging to immigrant groups where religiousness is a common identity marker was shown in some studies to raise their levels of religious affiliation and religiosity (van Tubergen 2007; Hagan and Ebaugh 2003).

Religious supply theory (Finke and Iannaccone 1998; Bruce 2000) posits that religious following is explained by churches behaving similarly to clubs or firms in a competitive market, and especially seeking to provide the services that attract more potential followers - if various religious groups and institutions in Canada provide services and offers that may meet different needs than what the case was in their country of origin, then it could be in their interest to convert after migration.

\section{Concepts, data sources and methods}

The paper uses as its main religious concept the self-reported affiliation with a religious group. Accordingly, religious switching is analysed in terms of changes in self-reported affiliation according to the following categories: Catholic, Protestant, Orthodox 
Christian, Other Christian, ${ }^{4}$ Muslim, Jewish, Buddhist, Hindu, Sikh, Other religions and No religion ${ }^{5}$.

The main data sources used for the analysis are the 1981, 1991 and 2001 longform censuses of Canada as well as the 2011 National Households Survey (NHS), a voluntary survey which replaced in 2011 the long-form census. These sources collect information on religious affiliation and other socioeconomic characteristics of the population (including place of birth) through a self-administered questionnaire distributed to large-scale samples of Canadian households. ${ }^{6}$

To keep measurements comparable at all points in time, the population living in non-institutional collective dwellings and the Canadians enumerated overseas (that were

${ }^{4}$ The Other Christian group includes mostly people who only report “Christian”, without further specification, when asked about their religion.

${ }^{5}$ The religious categories were defined consistently across censuses based on the 2011 Statistics Canada classification (see Appendix 1.7 in Statistics Canada 2013-2). However some adjustments were needed for the Protestant category which was used in previous Statistics Canada’s classifications, but was no longer used in the 2011 classification. Instead, the denominations were reported only separately (Anglican, Baptist, etc.). For this reason, we used the 2001 census classification (see Statistics Canada 2003, Appendix L) to construct the Protestant group. Further minor adjustments and exclusions, mostly involving the "Other religion” group, were necessary to match this classification and make data comparable over time. These are not significant and do not affect the analysis.

${ }^{6}$ The sample size increased from 4.9 million in 1981 to 6.7 million in 2011. Given that the religion question is asked only every ten years, it was not possible to use the 1986, 1996 and 2006 censuses. 
not part of the population covered by the 2011 NHS) were excluded from the analysis. ${ }^{7}$ For the same reason, non-permanent residents were excluded from the 1991, 2001 and 2011 databases (they were not enumerated in 1981). The data for all years were adjusted for net undercoverage by age, sex and province/territory. ${ }^{8}$ It is worth noting that the question on religion is identical in the NHS and censuses with the exception of the 1981 census, where the labelling of answers was different. From 1991 to 2011, the question included an open-end field to report the religious affiliation and a check box for the No religion category; the 1981 question provided instead check boxes for the 15 main affiliations (including No religion) and an open-end field for other religions ${ }^{9}$.

The other data source used, the 2002 Ethnic Diversity Survey, is a nationally representative interview-survey conducted only once, after the 2001 census. ${ }^{10}$ It includes a similar question on religion as in the censuses/NHS but also questions the respondent on the religion of both mother and father when he/she was aged less than 15, as well as questions on other characteristics, including immigrant status.

${ }^{7}$ These populations comprise between $0.4 \%$ and $0.7 \%$ of the total population depending on the census year.

${ }^{8}$ Net undercoverage is the difference between overcoverage and undercoverage. It is estimated by Statistics Canada after each census.

${ }^{9}$ We checked comparability over time of the census/NHS estimates and GSS data (from 1985 to 2010) for the main affiliations and found both sources to be consistent. Results are available from the authors upon request.

${ }^{10}$ The EDS sample size is 42,476 . 
The analysis is conducted in two distinct parts. In the first part, we perform a cohort analysis using the 1981, 1991 and 2001 censuses and the 2011 NHS, following a methodology similar to that used by Anderson and Silver (1983) in their paper on the "russification" of ethnic minorities in the U.S.S.R. and by Khoo (2006) to assess changes in self-reported ethnic origins in Australia. The main purpose of the method is to assess, for each religion, and using only census/NHS data, the net population growth/decrease that remains unexplained after we control for births, deaths and migrations during a given period, the unexplained growth being interpreted as the result of religious switching. This allows us to answer the research questions on the magnitude and trend of religious switching among the immigrant population to Canada and to compare it to that of the Canadian-born population.

The method, in this paper, is applied to series of subsequent points in time: between 1981 and 1991, 1991 and 2001, as well as 2001 and 2011. More precisely, the following procedure was implemented for both immigrants by place of birth, and nonimmigrants.

- Step 1: We adjusted for births and immigration which happened during the period. To do so, we first removed from the population at the end point of a given 10-year period (e.g. the 1991 population for the period 1981-1991) the children aged less than 10 years old (the births that have occurred during the period) and the immigrants admitted within the period (e.g. immigrants enumerated in 1991 who arrived between 1981 and 1991). Thus, the resulting population at the end of the period only includes people who were already part of the population at the beginning of the period. 
- $\quad$ Step 2: We adjusted for mortality and emigration. To do so, we calculated a ratio of the total adjusted population at the end of the 10-year period (excluding births and immigrants as shown in step 1) to the total population at the beginning of the period. The ratios, which do not account for religion at this point, were computed by place of birth (country or subcontinent) and age group. They represent the percentage of the population, by place of birth and age group, who survived to the combined effects of mortality and emigration during the period. ${ }^{11}$

- Step 3: The ratios from Step 2 were applied to the population at the beginning of the period by place of birth, age group and religion, thus assuming the same combined effects of mortality and emigration for all religions by place of birth and age group over the ten-year period. ${ }^{12}$ The population resulting from Step 3 represents the expected population by religion at the end of the period, under the assumption of no religious switching.

- Step 4: We finally compared this expected population by religion to the observed end-of-period adjusted population obtained from Step 1 by religion. The difference between the counts thus obtained is assumed to come from individual changes in self-reported religious affiliation or, in other terms, from

\footnotetext{
${ }^{11}$ It also includes the coverage errors not captured by the adjustments made on the databases.

${ }^{12}$ This method should give similar results as if we had applied the same mortality and emigration rates to every religious groups for a given place of birth. However, data for these components by place of birth are not available for all periods.
} 
religious switching. The estimates are interpreted as representing the net gains or losses through religious switching experienced in Canada by the population already in Canada at the beginning of the period.

Although this method was felt to be the most appropriate, it has several drawbacks. First of all, although the methodology allows for the assessment of the religious switching of immigrants and non-immigrants, it does not provide estimates of the specific origin-destination flows between religions due to religious switching. It only provides its net effect by religion. As such, it does not allow assessing the propensity to change religion, as net gains and losses thus obtained are always the result of in- and out- flows. It is also limited for the analysis of characteristics associated with religious switching.

Since the former data challenge could not be solved with censuses/NHS, we used, as a complement, the answers given by the EDS respondents to the questions on their religion as well as on the religion of their parents when respondents were aged less than 15 years old to analyse religious switching by religion of origin (that of the parents) and of destination (respondent's religion), by various socioeconomic characteristics. This helps us to specify the direction of religious switching and to analyse the socioeconomic characteristics associated with religious mobility.

The EDS includes separate questions on the religion of the respondent's mother and the father, which allows for estimating intergenerational religious switching from the point of view of both parents separately. In this study, when using EDS, we do not consider the respondents as having changed religion when their religion is shared with at least one of their parents. Conversely, respondents are considered as having been 
religiously mobile if their religion is different compared to that of both their mother's and father's.

This definition causes some challenges for the analysis of religious switching patterns by origin and destination because in case of interreligious unions, there are two origins for one destination. In these cases, the religion of origin was classified as follows:

- When the respondent's religion is shared by one of the parent, the religion of origin is considered to be the same as the religion of destination.

- When a change of religion is recorded, two distinct joint distributions were computed, one with the mothers' religions as the origin and another one based on the fathers' religion. The results of the two tables were then averaged. This last procedure gives the same result as if we would have classified the respondent's religion of origin equally between the religion of the mother and that of the father (giving each a weight of 0.5 ).

The EDS data also have several limits. First of all, it is not possible to know when respondents changed their religion (e.g. before or after immigration to Canada) if they did, nor if they changed once or more than once over the course of their life. As well it is worth noting that this data on religious switching is not fully comparable to that obtained through calculations in the first part which is based on the respondent's religion, whereas the EDS has an intergenerational perspective. Also, while the data in the first part provides estimates over a 10-year period, the time span in the EDS varies from one respondent to the next. However, the presence or lack of similarities between 
both data sources when it comes to net changes between religions is useful for the interpretation of the results.

\section{Analysis of results}

\section{Religious switching over ten-year periods as measured with censuses/NHS data}

The results in terms of the net religious switching of immigrant and non-immigrant populations are displayed in Figure 2. Each bar represents the net gains (positive numbers) or losses (negative numbers) of persons due to religious switching for each religion in three ten-year periods: 1981-1991, 1991-2001 and 2001-2011.

A first observation that can be drawn from this graph is that religion is not a fixed attribute of immigrants and that they are religiously mobile after their arrival in Canada. In absolute numbers, the largest net switching out of religion for the immigrant population was experienced by the Catholics and the Protestants. For the immigrants living in Canada in 1981, Catholics and Protestants lost together a net number of persons of 103,000 in the following ten years; the net losses were 76,000 between 1991 and 2001 and 163,000 between 2001 and 2011 for the immigrant population living in Canada at the beginning of each period. The Catholics distinguished themselves from the Protestants in terms of net religious switching since they experienced fewer net losses in absolute numbers for all periods, especially in 1991-2001, even if the volume of mobile population has swollen since 2001. The recent increase is also visible for Protestant immigrants. If we look at religious affiliations that have increased their totals by switching, we can see that the No religion group and the Other Christian religions are gaining in all periods. The net gains increased over time for the Other Christian 
group, while they were lower in 1991-2001 for the unaffiliated. Among the other affiliations, religious switching has been experienced by growing minority religions such as Islam (net losses mostly in the period 2001-2011) Sikhism (net gains across the whole period) and Buddhism (net losses between 1981 and 2001 and net gains for 20012011). Most numbers for these groups are small however and given the residual nature of the method used to prepare the estimates, they must be interpreted with caution.

Figure 2 also shows that the patterns of switching of the immigrant population resemble that of the non-immigrant population in several ways. As is the case for the immigrant population, Catholics and Protestants experienced net losses across all periods, with increased losses between 2001 and 2011. Both the No religion and Other Christian groups experienced net gains, suggesting that many Catholics and Protestants switched to these religions. In absolute numbers, the net religious switching is lower for the immigrant than for the non-immigrant population. But given differences in size between the immigrant and non-immigrant populations, we need to assess the relative impact of religious switching on the two populations.

[Insert Figure 2 about here]

Figure 3 presents net gains and losses through religious switching in percentage of the population for each religious group, both for the immigrants and the nonimmigrants from 1981-1991 to 2001-2011. For the immigrant population, it shows that the net losses among Catholics contributed only to small decreases in population, between 1\% between 1991 and 2001 to 4\% between 2001 and 2011. For the Protestants, the net losses in percentage increased over time, from 4\% in 1981-1991 to 8\% in 2001- 
2011. Given the population size of these two groups, the losses translated in relatively large flows for 'receiver' groups with smaller populations, especially the Other Christian (all periods) and the Buddhists between 1981 and 2001. The impact on population size of religious switching decreased for the two groups, as well as for the Sikhs, as their population grew. Christian Orthodox experienced consistent net losses representing between $2 \%$ and $5 \%$ percent of their population depending on the period, while the rates for the Jewish population remain close to zero in all periods. For the No religion, the greatest impact of religious switching on population growth happened in 1981-1991 (16\%), followed by 2001-2011 (14\%). The impact of religious switching on the unaffiliated population was smaller between 1991 and 2001 (1.5\% net gains).

[Insert Figure 3 about here]

Among the non-immigrant population, the net losses in percentage were usually greater compared to the immigrant population, especially for the Catholics between 2001 and 2011 (7\%) and for the Protestants across all periods (8\%, 9\% and 16\%). It was also the case in all periods for the Christian Orthodox. It translated into largest relative contribution to population increases for Other Christians (except in 1981-1991), Buddhists, Other religions ${ }^{13}$ and the No religion group. Religious switching looks like having contributed more to changing the religious composition among the nonimmigrant population than the immigrant population, at least after 1991. But the differences between the two populations could be due in part to an age effect, the immigrants being close to 30 years of age on average when they arrive in Canada,

\footnotetext{
${ }^{13}$ Given the small counts and the heterogeneity within the 'Other religions' group, numbers have to be interpreted with caution.
} 
which is after the peak-age at religious switching according to the literature (see for instance Iannaccone 1990 and Iannaccone 2006). However, after checking, data only support this assumption for the 1981-1991 period, the following two periods being characterized by higher net changes for non-immigrants of almost all ages below 50, including the peak ages at the turn of the $20 \mathrm{~s}^{14}$.

Results presented so far give a picture of the total immigrant population, which is not homogeneous as it is composed of people with various backgrounds. As a consequence, some results presented earlier might be associated with specific patterns of religious switching related to specific groups of immigrants. Even if the residual nature of our method combined with small counts prevent us from performing a detailed analysis by country of birth, it remains possible to present net religious switching for the main religious groups by continents of birth of immigrants.

Figure 4 shows that for most continents of birth and periods, Catholic and Protestant groups generally experienced net losses due to religious switching, while the gains were usually concentrated amongst the No religion and Other Christian groups, the pattern being especially clear for immigrants born in Europe and the Americas. The numbers for Africa are, for most of them too small to be interpreted. Asian immigrants present some specific patterns of religious switching. While Catholics, Protestants and Other Christians present similar patterns as the population born in other continents, Asian immigrant population is the only one experiencing net losses to the No religion group, in 1981-1991 and 1991-2001. Immigrants from China (including Hong-Kong)

\footnotetext{
${ }^{14}$ This analysis is not presented here and can be provided by the authors upon request.
} 
contributed largely to these losses (data not shown). The net gains of the No religion group for Asia overall in 2001-2011 came largely from increased disaffiliation rates for the immigrants born in West Central Asia and the Middle East, and by increased net losses among Muslim immigrants (data not shown). To a lesser extent, the gain of the No religion group in 2001-2011 can be explained by a reversal within the immigrant population born in other East-Southeast Asian countries, from net losses until 2001 to a net gain of persons in the No religion group.

[Insert Figure 4 about here]

\section{Life-time religious switching as measured with EDS data}

The 2002 Ethnic Diversity Survey allows for the analysis of religious switching of immigrants under a different perspective, focusing on changes in religious affiliation of respondents compared to that of their parents when respondents were children aged less than 15. To get an overview of the global picture emerging from the EDS data, and on how it compares with the census/NHS counts, we first computed net gains and losses by religion for both immigrants and non-immigrants, similar to Figure 2 above. Results from the EDS (Figure 5) show patterns of religious switching that are similar in many ways to those obtained with census/NHS data [see Figure 2], with net losses for Catholics and gains for the No religion and Other Christian groups among the immigrants. Among the non-immigrants, we still observe net losses for Catholics and Protestants and net gains for the No religion and Other Christian groups. As such, EDS 
results reinforce certain conclusions presented earlier. The few differences found (e.g. for the Buddhists or the Protestant immigrants) could be attributable to the conceptual differences between the sources used, as explained in the "Concepts, data sources and methods" section.

[Insert Figure 5 about here]

If we decompose the net religious changes in their underlying in- and outmovements (Table 1), ${ }^{15}$ we first see that the large majority of EDS immigrant respondents, for each large religious group, report having the same religion as at least one of their parents. However religious switching also exists among immigrants. For instance, the percentage who reported a different religion than both parents is $11 \%$ for respondents with a Catholic parental background, 19\% when the background is Protestant, $22 \%$ for respondents with a no religion background and $26 \%$ for other Christians. In the two latter groups, the relatively high rates of religious switching suggest that the net gains experienced by the unaffiliated and other Christians groups that has been observed with both data sources (EDS as well as census/NHS) are due only to high levels of entries.

[Insert Table 1 about here]

Also, if the phenomenon appears to be clearly multidirectional, a few patterns can be identified. First, as expected, No religion is the main 'ddestination' of immigrant

\footnotetext{
${ }^{15}$ Given sample sizes, the non-Christian religions were grouped together in Table 1.
} 
respondents who change affiliation compared to parents (more than $40 \%$ of all changes, driven by respondents with Protestants and Catholics backgrounds). Second, when Christians convert to another affiliation, they usually convert to a religious denomination within the Christian family, Catholics converting mostly to Protestant and Other Christian while Protestants mostly convert to Catholicism and to other Christian faiths. Finally, EDS data show very few occurrences of conversions to non-Christian religions, all existing flows being too small to be presented. It is worth noting that all these conclusions are not specific to immigrants and also hold for non-immigrants.

Results described so far show that net religious switching among immigrants depends on the initial religious background. They also tend to suggest that the choice of a new affiliation also depends on the individual background. Among the hypotheses that could be brought to explain these patterns, one explanation is that if the composition of the population of various religious background differ, the patterns of religious switching observed could have to do with these differences. Indeed, as seen earlier, religious switching has been found in the literature to be associated with characteristics such as age, place of birth or time elapsed since immigration. EDS data allow to test this hypothesis. We do not compare the various origin-destination flows due to small frequencies and sample sizes. Rather, we test if the propensity to quit a religion (or the no religion group) among immigrants remains related to the parental religious background after controlling for characteristics likely to differ from one religious group to another and likely to be associated with higher or lower levels of religious switching. To do so, we used EDS data to perform a logistic regression to estimate the odds for the immigrants of having reported a religion different from both their parents according to 
selected characteristics. ${ }^{16}$ Given that respondents may have parents with different religions, the religious background categories were defined using combinations of mother's and father's religions. Mixed unions are restricted to four large categories, the other possibilities having small sample sizes in the EDS. The odds ratios obtained are presented in Table 2.

Regression results show that the propensity of religious switching of immigrant respondents remains associated with the religious background of the parents when other factors are controlled. Respondents with both parents being Protestants, other Christians, Buddhists or having no religion were more likely to have changed religion than Catholics, while the respondent with two Sikhs parents were the less mobile. The propensity to be religiously mobile for respondents with parents in an interreligious union is relatively high, except when one parent was either Protestant or Catholic and the other parent had no religion. In the case of children of an interreligious union between a Catholic and a Protestant, the vast majority of the switches benefited to the no religion group. This is not the case for the mixed - other category, in part due to the fact that about half of interreligious unions in this category involve an unaffiliated parent, thus diminishing the possible number of switches to no religion (data not shown). It is worth noting that the two types of mixed unions showing relatively low levels of switching involve parents in the groups between which the changes are usually the most frequent: protestant and no religion as well as catholic and protestant. The

\footnotetext{
${ }^{16}$ The regressions were performed on the population aged 25 and over to obtain a clearer view of the relationships between education -still not final for large parts of the population aged less than 25- and religious switching.
} 
retention rate is especially high for immigrants with protestant and no religion parents, about 95\% still being either protestant or unaffiliated.

As to respondents' characteristics used as controls, religious switching is higher for immigrants born in both the United States and the rest of the Americas compared to immigrants born in Europe, while immigrants born in Asia and Africa do not significantly differ from the immigrants born in Europe when controlling for other factors. Religious switching is also related to education, being more prevalent among respondents with post-secondary education. The results for immigrants do not show a significant effect of time elapsed since immigration, nor of gender. As for age, since the EDS provides only age of respondent, not age when the person converts or disaffiliates, the results are blurred by the cumulative nature of the process and generational effects.

[Insert Table 2 about here]

\section{Conclusion}

This study aimed to assess the validity of the hypothesis that is often made that immigrants keep the religious affiliation that they had upon arrival in the country of destination. Most migration and religious scholars assume this trait to be a part of the identity of migrants that will not change, and therefore the question is not studied, although many studies look closely at the trends in religious intensity and at that of the subsequent generations originating from the migration. At a time when religious diversity in many countries is increasing, it is interesting to see what is the religious path of migrants after arrival, not only in terms of religious intensity but also affiliation, and particularly whether the trends in terms of disaffiliation that are prevalent among the native populations of North America and Europe, are also seen among the migrants. 
We do this in the context of Canada, a country with relatively high immigration and increasing religious diversity. We assess whether immigrants to Canada are religiously mobile and compare their switching patterns to that of the non-immigrant population across time and according to some characteristics.

Our findings obtained with census/NHS data show that the immigrant population were indeed religiously mobile between 1981 and 2011 and shared in that regard many similarities with the non-immigrant population. As is the case for nonimmigrants, the Catholic and Protestant immigrants lost population through religious switching over time, meaning that part of the demographic contribution of the immigration to the two largest affiliations in Canada has been offset - but not fully - by changes in religious affiliations after arrival. These losses seem to have been experienced partly within the large Christian family, benefiting the 'other Christian' group, a fast growing affiliation about which not much is known. Further research on the specificities of the population joining this group, especially the differences in religious beliefs and practices of the persons reporting only 'Christian' when compared to Catholics and Protestants, would be beneficial to the understanding of the phenomenon of conversions in Canada. However, the group which experienced the largest net gains in absolute numbers over the period considered, both for immigrants and non-immigrants, is the no religion group, whose population has now surpassed that of the Protestant in Canada (Morency et al. 2017).

Even if observed for most places of birth, the disaffiliation trend is not the norm for all immigrants: In particular, and consistently with results obtained by Beyer (2005) and Skirbekk et al. (2012), the Chinese tend to affiliate after migration. This may be 
related to their specific religious background - the majority reporting no religion upon arrival.

This study faced several limitations. First, in the absence of recent longitudinal datasets, indirect methods were applied to measure religious switching. Even if appropriate precautions were taken to maximize comparability between censuses (adjustments for undercoverage, exclusion of sub-populations, controls for components of growth), the method results in net changes which do not allow for the measurement of flows, and renders difficult the analysis of small changes given the residual nature of the procedures. But it nevertheless shows clear and consistent patterns over time, which were in their main conclusions echoed by an external / independent data source-2002 EDS. The methods used could also be applied to other countries where similar data are available.

Also, the study focused on changes between large religious affiliations, and thus ignores switching between religions within the same group (e.g. between United Church of Canada and Lutherans, both classified as Protestants), which might happen actually quite frequently as suggested by Bibby (1997). On the other hand, the Christian affiliations are divided between four affiliations, Catholics, Protestants, Orthodox and other Christians while we do not consider, due to data limitations, denominational switching within other large religions e.g. Muslim affiliation between Shi'a, Sunni, and other denominations. Although this might lead to an overestimation of switching among Christians relative to switching among other groups, most of the switching still happens to the unaffiliated groups. We did not lump the results together as it seems important to see the difference in switching between the main Christian denominations. 
All in all, we show that immigrants are less religiously mobile than nonimmigrants in the most recent period. Continuation of these trends in a context where the foreign-born population is projected to increase, could lead to lower levels of overall religious switching in the coming years. However, changes in the composition of immigration to Canada or of mixed unions as diversity spreads in the population could be associated with changing patterns in religious switching. It would be interesting to see whether the results found in Canada hold for other Western countries with similarities in the composition of their immigrant populations. This study shows that religious switching is related to individuals' background, but patterns of religious switching may also depend on the context in the country of destination which could be revealed by comparisons with other countries. It would also be interesting to analyse the phenomenon among the second generation in Canada, which is growing in size and changing in composition, but whose religious switching patterns remain understudied.

\section{References}

Anderson, B.A. and B.D. Silver. 1983. 'Estimating russification of ethnic identity among non Russians in the USSR', Demography, 20(4).

Beyer, P. 2005. 'The future of non-Christian religions in Canada: Patterns of religious identification among recent immigrants and their second generation, 1981-2001', Studies in Religion / Sciences Religieuses, 34 (2): 165-195.

Bibby, R.W. 1993. Unknown Gods: The Ongoing Story of Religion in Canada. Toronto: Stoddart

Bibby, R.W. 1997. 'Going, Going, Gone: The Impact of Geographical Switching on Religious Involvement', Review of Religious Research, 38(4): 289-307. 
2000. ‘Canada's Mythical Religious Mosaic: Some Census Findings’, Journal for the Scientific Study of Religion, 39 (2): 235-239.

- 2002. Restless Gods: The Renaissance of Religion in Canada, Ottawa, Novalis.

2012. A New Day: The Resilience and Restructuring of Religion in Canada, Project Canada Books.

—. 2007. Nevers, Nones, and Nots: Latent Life in Unexpected Places A Research Note, http://001a339.netsolhost.com/images/NNNpaper07.pdf.

Breen, R. and B.C. Hayes. 1996. 'Religious Switching in the UK', Journal of the Royal Statistical Society, 159(3): 493-504.

Bruce, Steve. "The Supply-Side Model of Religion: The Nordic and Baltic States." Journal for the scientific study of religion 39.1 (2000): 32-46.

Chui, T., K. Tran and H. Maheux. 2007. Immigration in Canada: A Portrait of the Foreign-born Population, 2006 Census, Statistics Canada Catalogue no. 97-557. Clark, W. 2006. 'Interreligious unions in Canada', Canadian Social Trends, Statistics Canada Catalogue no. 11-008.

Colom Gonzalez, F., D'Amato, G. [eds] 2016. 'Multireligious Society: Dealing with Religious Diversity in Theory and Practice’’ Boca Raton, Florida: CRC Press.

Connor, P. 2008. 'Increase or Decrease? The Impact of the International Migratory Event on Immigrant Religious Participation', Journal for the Scientific Study of Religion, 47(2): 243-257.

—. 2009. 'Immigrant Religiosity in Canada: Multiple Trajectories', Journal of International Migration and Integration / Revue de l'intégration et de la migration internationale, 10(2), May 1: 159-175. 
Crockett, A. and D. Voas. 2006. 'Generations of Decline: Religious Change in $20^{\text {th }}$ Century Britain', Journal for the Scientific Study of Religion, 45(4): 567-584.

Ebaugh, H.R. and J.S. Chafetz. 2000. 'Structural Adaptations in Immigrant Congregations’, Sociology of Religion, a Quaterly Review, 61(2): 135-153.

Eid, P. 2007. La ferveur religieuse et les demandes d'accommodement religieux: une comparaison intergroupe, Commission des droits de la personne et des droits de la jeunesse du Québec, Catalogue no. 2.120-4.21

Ellison, Christopher G., and Jeffrey S. Levin. "The religion-health connection: Evidence, theory, and future directions." Health Education \& Behavior 25.6 (1998): 700-720.

Engelberg, Joseph, et al. "Human capital and the supply of religion." Review of Economics and Statistics 98.3 (2016): 415-427.

Finke, Roger, and Laurence R. Iannaccone. "Supply-side explanations for religious change." The Annals of the American Academy of Political and Social Science 527.1 (1993): 27-39.

Fleischmann, F. and K. Phalet. 2012. 'Integration and religiosity among the Turkish second generation in Europe: a comparative analysis across four capital cities', Ethnic and Racial Studies, 35(2): 320-341.

Foner, N. and R. Alba. 2008. 'Immigrant Religion in the U.S. and Western Europe: Bridge or Barrier to Inclusion?’, International Migration Review, 42(2): 360-392. Goujon, A., V. Skirbekk, and K. Strzelecki Fliegenschnee. 2007. 'New Times, Old Beliefs: Projecting the Future Size of Religions in Austria’, Vienna Yearbook of Population Research, 237-270. 
Goujon, A, É. Caron Malenfant and V. Skirbekk. 2015. 'Towards a Catholic North America?', in Stanley D. Brunn (ed.), The Changing World Religion Map: Sacred Places, Identities, Practices and Politics, Springer.

Goujon et al. 2014. WIREL project key findings: Religions in Vienna in the past, present and future. Vienna: Vienna Institute of Demography.

Goujon, A. and R. Bauer. 2015. Demographic forces shaping the religious landscape of Vienna, Chapter 9.3, Volume 4. In Brunn, S. D. (ed), The changing world religion map. Springer Netherlands: 2145-2161.

Hagan, J. and H.R. Ebaugh. 2003. ‘Calling Upon the Sacred: Migrants’ Use of Religion in the Migration Process', International Migration Review, 37(4): 1145-1162.

Halman, L. and O. Riis. 2003. Religion in a secularizing society: The Europeans' religion at the end of the $20^{\text {th }}$ century. Leiden and Boston: Brill.

Herberg, W. 1960. Protestant--Catholic--Jew: An Essay in American Religious Sociology. The University of Chicago Press Books

Iannaccone, L. R. (2016). Rational choice. Rational choice theory and religion: summary and assessment.

Iannaccone, L.R. 2006. 'Economy’, in Helen Rose Ebaugh (ed.), Handbook of Religion and Social Institutions, New York, NY: Springer Iannaccone, L.R. 1990. 'Religious Practice: A Human Capital Approach’, Journal for the Scientific Study of Religion, 29(3), September 1: 297-314.

Inglehart, R. and P. Norris. 2009. Muslim Integration into Western Cultures: Between Origins and Destinations, HKS Working Paper No. RWP09-007, Harvard Kennedy School (HKS), Cambridge, MA, United States.

Khoo, S. 2006. 'Stability and change in ethnic identification in Australia: An aggregate analysis', Journal of Population Research, 23(1). 
Maliepaard, M., M. Lubbers and M. Gijsberts. 2010. 'Generational differences in ethnic and religious attachment and their interrelation. A study among Muslim minorities in the Netherlands', Ethnic and Racial Studies, 33(3): 451-472.

Morency, J.D., É. Caron-Malenfant and S. MacIsaac. 2017. Immigration and Diversity: Population Projections for Canada and its Regions, 2011 to 2036. Ottawa. Statistics Canada.

Pew Research Center. 2013. 'Canada's Changing Religious Landscape’, http://pewforum.org/2013/canadas-changing-religiouslandscape/?utm_expid=53098246-2.Lly4CFSVQG2lphsg-Koplg.0\#overview (consulted December $7^{\text {th }}$ 2015).

Pew Research Center. 2015. The Future of World Religions: Population Growth Projections, 2010-2050.

Rahman, S.A. 1986. Punishment of Apostasy in Islam, Lahore, Kazi Publications. Rambo, L. and C. Farhadian (eds). 2014. The Oxford Handbook of Religious Conversion. Oxford University Press.

Rambo, L.R., S. Bauman and J. Fengjiang. 2012. 'Toward a Psychology of Converting in the People’s Republic of China’, Pastoral Psychology, 61(5-6), December 1: 895921.

Skirbekk, V., A. Goujon and E. Kaufmann. 2010. 'Secularism, Fundamentalism, or Catholicism? The Religious Composition of the United States to 2043', Journal for the Scientific Study of Religion, 49(2): 293-310.

Skirbekk, V., É. Caron Malenfant, S. Basten and M. Stonawski. 2012. 'The Religious Composition of the Chinese Diaspora, Focusing on Canada', Journal for the Scientific Study of Religion, 51(1): 173-183. 
Skirbekk, V., Potančoková, M., Hackett, C., \& Stonawski, M. (2016). Religious

Affiliation Among Older Age Groups Worldwide: Estimates for 2010 and Projections Until 2050. The Journals of Gerontology Series B: Psychological Sciences and Social Sciences, gbw144.

Statistics Canada. 2014. Population Projections for Canada (2013 to 2063), Provinces and Territories (2013 to 2038), Statistics Canada Catalogue no. 91-520.

Statistics Canada. 2013, Immigration and Ethnocultural Diversity in Canada : National Household Survey 2011, Statistics Canada catalogue no. 99-010.

Statistics Canada. 2013-2. National Households Survey Dictionary, 2011, Statistics Canada catalogue no. 99-000.

Statistics Canada. 2008. Canadian Demographics at a Glance, Statistics Canada catalogue no. 91-003.

Statistics Canada. 2003. 2001 Census Dictionary. Statistics Canada catalogue no. 92378.

Stonawski, M., Skirbekk, V., Hackett, C., Potancokova, M., Connor, P., \& Grim, B. (2015). Global population projections by religion: 2010-2050. Yearbook of international religious demography, 2, 101-116.

Swatos, W.H and K. J. Christiano. 1999. "Introduction — Secularization Theory: The Course of a Concept.” Sociology of Religion 60(3): 209-228.

Van Cappellen, P., Toth-Gauthier, M., Saroglou, V., \& Fredrickson, B. L. (2016).

Religion and well-being: The mediating role of positive emotions. Journal of Happiness studies, 17(2), 485-505.

Van Tubergen, F. 2007. 'Religious Affiliation and Participation Among Immigrants in a Secular Society: A Study of Immigrants in The Netherlands', Journal of Ethnic and Migration Studies, 33(5): 747-765. 
Van Tubergen, F. and J.Í. Sindradóttir. 2011. 'The Religiosity of Immigrants in Europe: A Cross-National Study', Journal for the Scientific Study of Religion, 50(2): 272-288. Van Tubergen, Frank. 2013. 'Religious Change of New Immigrants in the Netherlands: The Event of Migration.' Social Science Research, 42(3)

Voas, D. 2003. 'Intermarriage and the Demography of Secularisation’, British Journal of Sociology, 54(1): 83-108.

Wolf, C. 2008. 'How Secularized Is Germany? Cohort and Comparative Perspectives’, Social Compass, 55: 111-126. 